\title{
Efektivitas Ruang Terbuka Publik pada Klaster Perumahan Komunitas Berpagar (Perumahan Bukit Baruga Kota Makassar)
}

\author{
Wahyudi Hasfi ${ }^{1}$, Shirly Wunas ${ }^{1}$, Idawarni Asmal ${ }^{1}$ \\ ${ }^{1}$ Departemen Teknik Arsitektur, Fakultas Teknik, Universitas Hasanuddin \\ Jl. Poros Malino km. 6, Bontomarannu, Kabupaten Gowa, Sulawesi Selatan 92171 \\ *Email: wahyudihasfi@gmail.com
}

DOI: 10.25042/jpe.052019.09

\begin{abstract}
Abstrak
Komunitas Berpagar (Gated Community) merupakan kawasan permukiman dengan akses terbatas membuat ruang publik menjadi privat. Tujuan dari penelitian ini adalah untuk mengetahui kondisi dan ketersediaan serta efektivitas ruang terbuka publik yang ada pada permukiman berkarakter Gated Community di Kota Makassar berdasarkan pengguna dan aktivitasnya dengan menggunakan metode campuran (mix methode) untuk mengamati dan menganalis data. Teknik analisis data dilakukan dengan metode GPSI (Good Public Space Index). Hasil Penelitian dapat disimpulkan bahwa : (1) Ketersediaan Ruang Terbuka Publik dalam Perumahan Bukit Baruga khususnya dalam Klaster Borneo telah memenuhi standar dengan luas $1.190 \mathrm{~m}^{2}$ dengan jumlah warga 628 orang (Syarat minimal $1 \mathrm{~m}^{2} /$ orang, berdasarkan Permen PU Nomor 05/PRT/M/2008); (2) Efektifitas penggunaan ruang terbuka publik berdasarkan analisis GPSI dari variabel Intensitas dan Durasi Penggunaannya adalah tidak efektif, sedangkan berdasarkan variabel Penggunaannya secara Berkelompok, Keragaman Penggunanya, serta Keragaman Karakteristik Penggunanya adalah efektif. Penelitian ini diharapkan dapat menjadi acuan evaluasi ruang terbuka pada komunitas berpagar sehingga efektifitas penggunaan ruang terbuka dapat tercapai secara maksimal.
\end{abstract}

\begin{abstract}
The Effectiveness of Public Open Space in Gated Community Housing Cluster. This study aims to explain in depth the physical conditions, the availability and The Effectiveness of Public Open Spaces in Gated Community Housing Cluster towards the users and their activities uses a mixed method to analyze and to explain data comprehensively. Data collection techniques utilized the method of verification through GPSI (Good Public Space Index). This research found that: (1) the availability of Public Open Space in Bukit Baruga Housing especially in the Borneo Cluster with 628 citizens has already fulfilled the standard of open space with the providing $1,190 \mathrm{~m}^{2}$ while minimum open space of $1 \mathrm{~m}^{2} /$ citizen (Permen PU Nomor 05/PRT/M/2008); (2) The effectiveness of the use of public open space is seen to be ineffective based on Intensity of Use and People's Duration Of Stay; it seems effective based on the Intensity of Social Use, Variety of Use and Diversity Of Use. This research is expected to be a reference in evaluating open space in gated communities so that the more effective implementation in utilizing open space can be achieved.
\end{abstract}

Kata Kunci: Efektifitas, komunitas berpagar, GPSI, ruang terbuka publik

\section{Pendahuluan}

Ruang terbuka publik merupakan sarana umum yg digunakan warga untuk saling berinteraksi yang parameter keberhasilanya adalah pemanfaatannya, sedangkan pemanfaatan dan kepopuleran sebuah ruang publik tergantung kondisi lingkungan dan detail dalam rancangannya. Dalam hal ini keduanya harus lebih terkomunikasikan yaitu keterkaitan antara rancangan tata lingkungan dengan pemanfaatan ruang publik, sehingga ruang publik tersebut memiliki daya tarik tersendiri bagi masyarakat untuk memanfaatkan dan beraktivitas di dalam ruang publik tersebut.

Isu yang diangkat pada penelitian ini adalah perencanaan ruang terbuka publik pada perumahan berkarakter gated community. Klaster dalam perumahan bukit baruga adalah pemukiman yang dihuni oleh komunitas yang cenderung homogen dalam taraf pendapatan yang menginginkan akses terbatas pada lingkungannya serta menjadikan sebuah ruang publik menjadi privat demi mewujudkan visi bersama dalam komunitas yaitu keamanan. Akses dalam klaster perumahan ini dikendalikan dan dibatasi oleh pembatas fisik serta gerbang dan penjaganya. Penelitian dalam klaster 
ini diharapkan dapat memberi gambaran mengenai kondisi dan efektivitas ruang terbuka publik dalam perumahan komunitas berpagar di Kota Makassar.

Untuk mengetahui hal tersebut, maka perlu dilakukan proses observasi berdasarkan ketersediaan fasilitas dan indeks GPSI. Menurut Carmona [1], Ruang kota harus menyediakan ruang publik yang cukup untuk memelihara interaksi antar penghuninya. Ruang publik ini sendiri terbentuk dari lingkungan alami dan buatan dengan kemudahan akses sebagai persyaratan yang utama. Pengamatan dan analisis terhadap kondisi dan pengguna ruang luar dapat dikembangkan sebagai salah pendekatan dalam kajian ruang publik terutama untuk menilai respon pengguna ruang terhadap kualitas dan efektivitas ruang terbuka publik. Menurut Carr [2], ruang terbuka publik yang baik harus memiliki tiga nilai intrinsik yaitu demokratis, bermakna dan responsif.

Aspek penting dalam ruang publik yang demokratis adalah tersedianya aksesibilitas yang baik. Dengan aksesibilitas yang baik, akan mendorong pemanfaatan ruang publik oleh pengguna yang beragam. Keberagaman pengguna ini dapat diukur dari keberagaman gender, usia dan beberapa karakteristik lainnya. Sebagai ruang yang responsif, ruang publik harus dapat memberi kenyamanan dan keleluasaan bagai pemanfaatan dan kegiatan yang beragam. Pada akhirnya, keberadaan interaksi sosial melalui terbentuknya kelompok pengguna ruang, intensifnya penggunaan ruang dan adanya aktivitas yang beragam dapat menjelaskan bagaimana ruang publik bermakna bagi masyarakat.

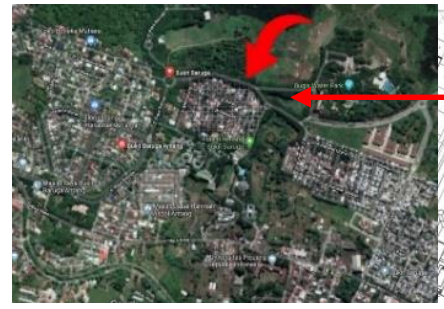

(a)

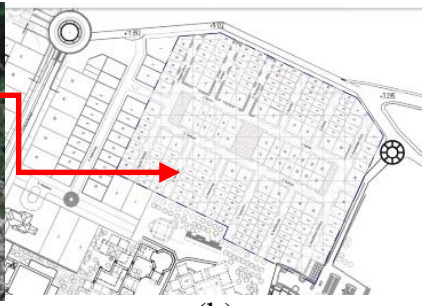

(b)
Gambar 1. (a) Citra Satelit area Klaster Borneo pada kawasan Perumahan Bukit Baruga. (b) Area lokasi

Perumahan bukit baruga direncanakan untuk menjadi kota mandiri yang berdiri di atas lahan seluas kurang lebih $300 \mathrm{Ha}$ yang terdiri dari beberapa klaster. Salah satu Klaster yang paling awal dibangun adalah klaster borneo.

\section{Metode}

\subsection{Jenis Penelitian}

Penelitian ini menggunakan Metode Campuran (mix method), metode kuantitatif untuk menganalisis data angka dari pengguna serta aktivitasnya kemudian metode deskriptif/kualitatif untuk mendiskripsikan dan menjelaskan kondisi, ketersediaan serta data angka yang dihasilkan.

\subsection{Lokasi dan Waktu Penelitian}

Lokasi Penelitian terletak di Perumahan Bukit Baruga, Jalan Tirtamaya, Antang, Kec. Manggala, Kota Makassar, Sulawesi Selatan. Waktu penelitian berlangsung pada akhir Bulan Agustus hingga Akhir Bulan September.

\subsection{Analisis Data}

Analisis data yang digunakan adalah deskriptif yang sifatnya memaparkan dan menjelaskan temuan hasil penelitian. Data diperoleh dari observasi atas ketersediaan dan kondisi dari ruang terbuka publik serta dari penggunanya yang akan diolah berdasarkan metode GPSI. Berdasarkan metode tersebut, beberapa informasi yang dibutuhkan, antara lain: (1) Intensitas Penggunaan Ruang Terbuka Publik, (2) Intensitas Penggunaan Secara Sosial (Bersama). (3) Durasi Penggunaan, (4) Keberagaman Aktivitas, serta (5) Karakteristik pengguna ruang luar (Mehta, 2007) [3]. Informasiinformasi di atas akan diolah menjadi data masukan untuk memperoleh index hasil yang akan memperlihatkan efektivitas ruang terbuka publik.

\section{Hasil dan Pembahasan}

Hasil penelitian ini mengenai (1) kondisi fisik fasilitas dalam ruang terbuka publik klaster borneo, (2) efektivitas ruang terbuka publik yang berdasarkan pengamatan dan pengumpulan data secara umum terhadap pengguna ruang terbuka. Adapun hasil tersebut adalah sebagai berikut: 
3.1. Ketersediaan ruang terbuka publik dalam klaster borneo

Ketersediaan fasilitas ruang terbuka publik pada perumahan bukit baruga khususnya di klaster borneo sudah memenuhi peraturan jika ditinjau pada aspek ketersediaan fasilitas, pada gambar dibawah, dapat dilihat luas total klaster borneo adalah 42.392,3 $\mathrm{m}^{2}$, sedangkan luas ruang terbuka publik yang disediakan adalah $1190 \mathrm{~m}^{2}$. Menurut Peraturan Menteri Pekerjaan Umum Nomor: 05/PRT/M/2008 [4], proporsi penyediaan ruang terbuka untuk lingkungan RT di kawasan perkotaan berdasarkan jumlah penduduk adalah minimal $1 \mathrm{~m}^{2} /$ warga. Dengan demikian dalam klaster borneo yang berpenduduk 628 orang warga harus menyediakan ruang paling tidak seluas 628 $\mathrm{m}^{2}$ sebagai ruang terbuka publik. Sehingga dapat dikatakan bahwa klaster borneo telah memenuhi standar yang disyaratkan oleh pemerintah dalam hal penyediaan ruang terbuka publik.

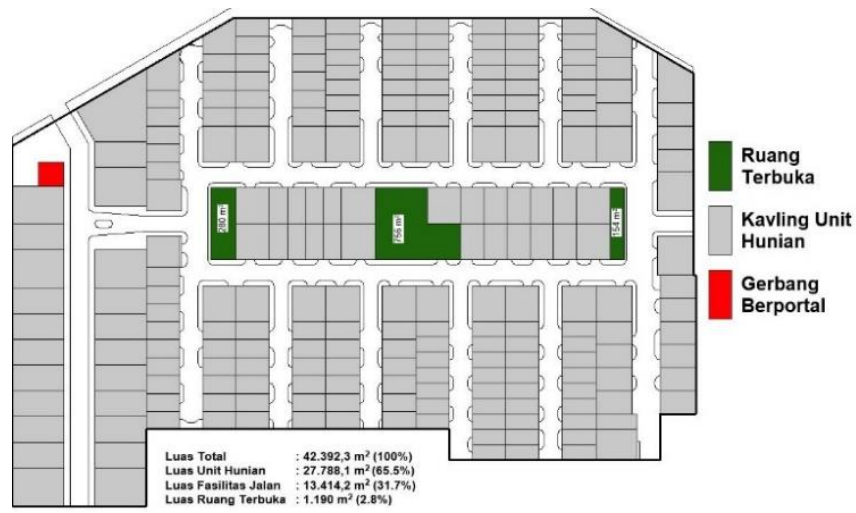

\section{Gambar 2. Letak dan ketersediaan ruang terbuka publik pada klaster borneo}

\subsection{Kondisi fisik fasilitas ruang terbuka publik}

Berdasarkan pengamatan pada aspek penggunaan maka ketersediaan fasilitas penunjang pada lokasi peneltian dinilai cukup memadahi untuk sebuah ruang terbuka bertaraf taman RT. Fasilitas penunjang pada ruang terbuka ini dilengkapi dengan berbagai fasilitas olahraga yang cukup mendukung pengunjung dalam beraktivitas.

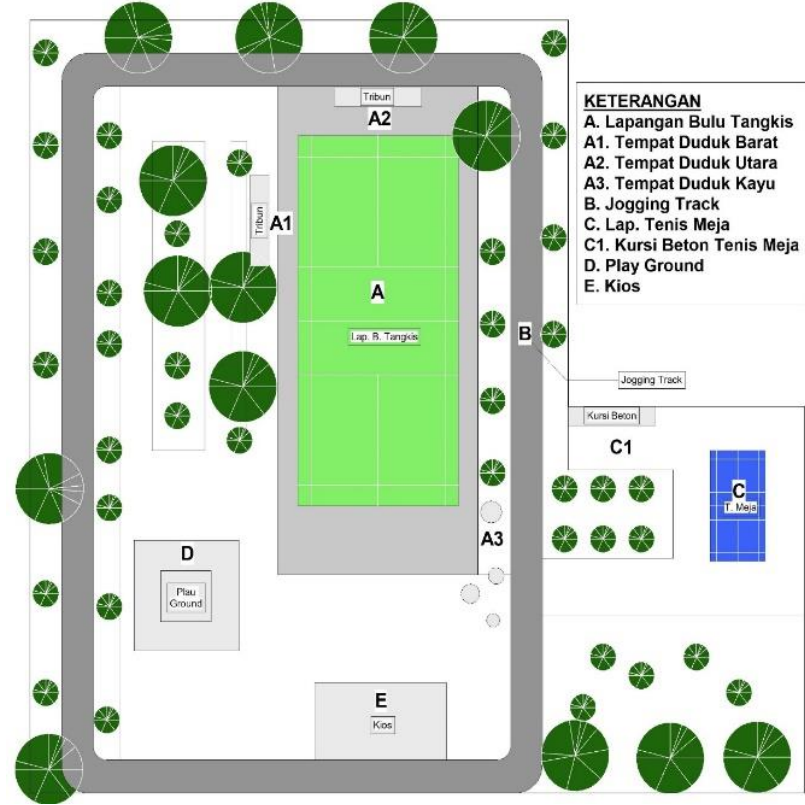

(a)

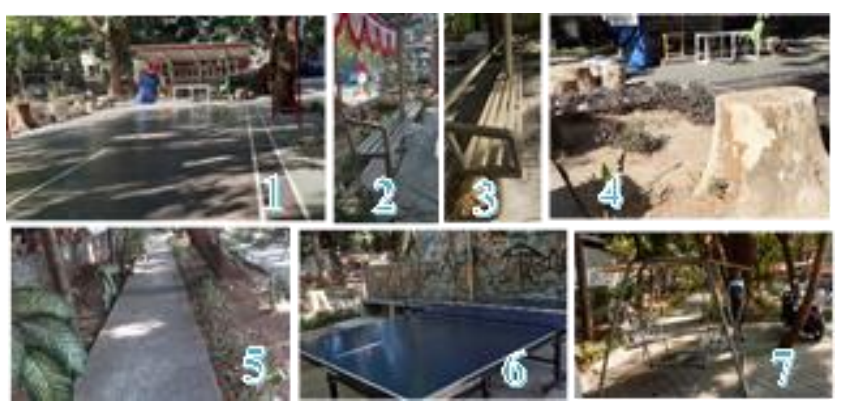

(b)

Gambar 3. (a) Peta letak fasilitas dalam ruang terbuka. (b). Kondisi fasilitas dalam ruang terbuka klaster borneo.

Gambar 1-4 merupakan area lapangan bulutangkis, tempat ini adalah lokasi favorit oleh semua warga untuk berkumpul dan melakukan berbagai aktivitas. Beberapa kali dalam setahun area ini digunakan oleh warga untuk melakukan kegiatan-kegiatan individual, hingga kegiatan bersama seperti perayaan kemerdekaan yang diisi dengan banyak perlombaan. Terlihat pada Gambar 2 \& 3 terdapat 2 tempat duduk di sisi lapangan bulu tangkis, kondisi fasilitas ini masih baik dan terawat. Selain Tempat duduk di sisi Barat lapangan bulu tangkis, juga terdapat tempat duduk di sisi timur yang terbuat dari potongan batang kayu dalam kondisi cukup baik terlihat pada Gambar 4. 
Gambar 5 area Jogging Track di dalam RTP klaster ini terlihat masih layak meskipun di beberapa bagian telah mengalami keretakan. Warga masih sering menggunakan fasilitas ini, selain untuk jogging, anak-anak sering menggunakannya untuk naik sepeda.

Gambar 6 Area lapangan tenis meja dalam klaster ini sebenarnya merupakan kavling rumah warga yang belum dibangun, kondisi lapangan masih baik dan terawat, meskipun dindingnya dipenuhi coretan. Fasilitas ini dilengkapi dengan atap kanopi sebagai peneduh. Gambar 7 Area Play Ground di dalam RTP klaster ini tidak begitu besar, hanya terdapat ayunan di dalamnya dan masih cukup baik kondisinya.

\subsection{Efektifitas ruang terbuka publik dalam gated community}

Hasil penelitian berdasarkan efektifitas ruang terbuka terbagi atas 5 analisis yaitu : analisis Intensitas penggunaan, penggunaan secara berkelompok, durasi pengguna, keragaman aktifitas, dan keragaman karakteristik pengguna. Berikut adalah hasil analisis tersebut :

\subsubsection{Intensitas penggunaan}

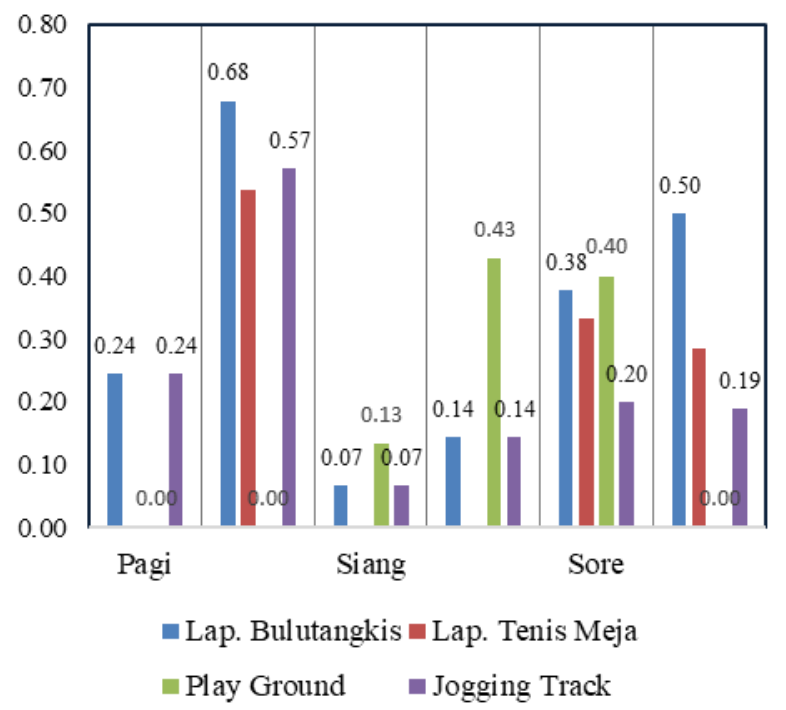

Gambar 4. Intensitas penggunaan berdasarkan aktifitas

Berdasarkan intensitas penggunaan terbagi atas 2 yaitu hari kerja (Senin-jumat) dan hari libur (Sabtu-minggu). Pada Gambar 4 Jumlah pengguna tertinggi hari kerja berdasarkan aktifitas berada pada sore hari di lapangan Bulu tangkis dengan nilai 0,38. Sedangkan untuk jumlah pengguna terendah berada pada pagi dan siang hari di lapangan tenis meja dan play ground dengan nilai 0 pengguna. Hal ini menunjukkan pengguna ruang terbuka di hari kerja lebih banyak menggemari lapangan bulu tangkis dibandingkan fasilitas lain dalam ruang terbuka yang tersedia.

Pada Gambar 4 diatas dapat terlihat dengan menggunakan indeks kualitas tertinggi (mendekati 1) yaitu Jumlah pengguna tertinggi hari libur berdasarkan aktifitas berada pada pagi hari di Lapangan Bulu Tangkis dengan nilai 0.68, sedangkan untuk jumlah pengguna terendah berada pada lap. Tennis meja dengan nilai 0 di siang hari dan jogging track dengan nilai 0 dalam 2 waktu, yaitu pagi dan sore hari. Hal ini menunjukkan bahwa Lapangan Bulu Tangkis masih tetap sebagai ruang terbuka yang paling popular dan diminati untuk digunakan terutama pada hari libur karena penggunanya yang kebanyakan anak-anak sekolah remaja dan para pekerja yang sedang libur.

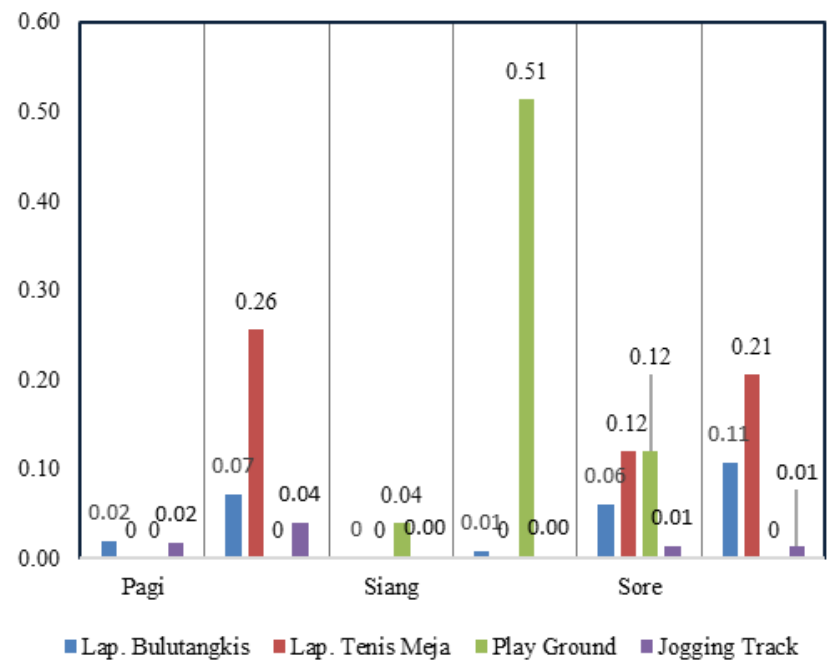

Gambar 5. Intensitas penggunaan berdasarkan luas ruangan

Pada Gambar 5 diatas dapat terlihat dengan menggunakan indeks kualitas tertinggi (mendekati 1) yaitu Jumlah pengguna tertinggi hari kerja berdasarkan luas ruang terbuka berada pada sore hari di Lapangan bulu tangkis dengan nilai 0,112 , sedangkan untuk jumlah pengguna terendah berada pada siang hari di lapangan tenis meja dengan nilai 0,005. Hal ini menunjukkan bahwa Lapangan bulu tangkis sebagai ruang terbuka masih lebih populer 
dibandingkan dengan ruang terbuka lain, terlebih lagi pada sore hari ketika pengguna pulang dari aktifitas bekerja dan sekolah.

Pada Gambar 5 juga dapat dilihat secara signifikan analisis jumlah pengguna berdasarkan luas ruang pada hari libur jauh lebih efektif dibandingkan dengan hari kerja, pada hari kerja nilai hanya berkisar $0,005-0,112$ sedangkan pada hari libur berkisar $0,03-0,514$. Pada hari libur jumlah pengguna tertinggi berdasarkan penggunaan ruangnya terdapat pada Play ground dengan nilai 0,514 , sama halnya dengan pada analisis jumlah pengguna berdasarkan aktifitas, pada analisis jumlah pengguna berdasarkan luas ruang menunjukkan Play ground cukup banyak digunakan pada hari libur terutama anak - anak yang libur sekolah sebagai sarana hiburan.

\subsubsection{Penggunaan secara berkelompok}

Berdasarkan analisis Gambar 6 diperoleh nilai ISU (Intensity of Social Use) yaitu 0,83 dan juga dapat kita lihat bahwa mayoritas fasilitas dalam ruang terbuka ini sangat dominan digunakan secara bersama. Hampir semua fasilitas dalam ruang terbuka ini, seperti Lapangan Bulu Tangkis, Tenis Meja dan Playground memang dibuat untuk digunakan secara berkelompok kecuali Jogging Track yang kebanyakan penggunanya adalah penggunaan secara individu. Hal ini menunjukkan efektifitas ruang terbuka terbukti efektif jika ditinjau berdasarkan penggunaan berkelompok, dalam artian interaksi sosialpun dalam ruang terbuka telah terjalin dengan baik.

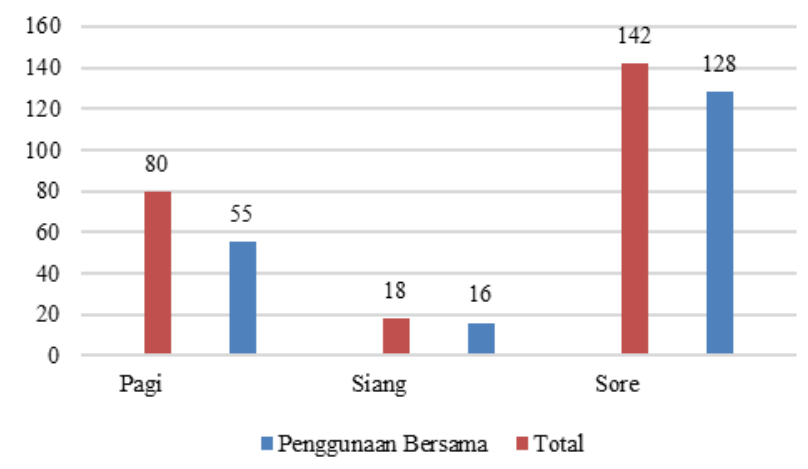

Gambar 6. Penggunaan secara berkelompok

\subsubsection{Durasi Pengguna}

Pada Gambar 7 diatas dapat terlihat pada hari kerja tingkat efektifitas penggunaan ruang terbuka dalam Klaster Gated community Perumahan Bukit Baruga cukup rendah yaitu berkisar $0-0,552$ berdasarkan indeks 0 - 1 terutama pada siang hari. Nilai terendah terdapat pada pagi dan siang hari pada lapangan tenis meja, pagi hari pada play ground, dan siang hari pada area jogging track dengan nilai 0 yang berarti tidak terdapat pengguna pada ruang terbuka tersebut. Hal ini dikarenakan pengguna sedang melakukan aktivitas diluar Gated community baik itu bekerja ataupun bersekolah bagi anak - anak.

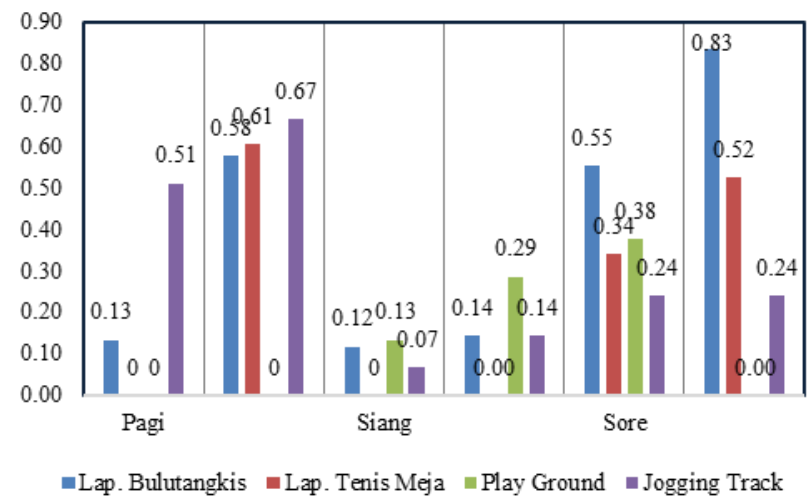

Gambar 7. Durasi pengguna

Sedangkan pada Gambar 7 diatas yaitu pada hari libur dapat terlihat pada analisis efektifitas ruang terbuka Gated Community Perumahan Bukit Baruga berdasarkan durasi kegiatan pada hari libur dapat dilihat penggunaan ruang terbuka cukup efektif yaitu berkisar antara $0-0.605$ meskipun rata-rata keseluruhan menunjukkan index yang masih rendah. Nilai tertinggi terdapat pada sore hari di Lapangan Bulutangkis, hal ini menunjukkan bahwa olahraga dan lapangan Bulutangkis sangat diminati, sedangkan untuk nilai terendah terdapat pada pagi dan sore hari di fasilitas Play ground.

Waktu penggunaan ruang terbuka publik dipengaruhi oleh apa yang ditawarkan tempat tersebut pada waktu tertentu. Rendahnya indeks kualitas pada tiap ruang terbuka publik berdasarkan waktu kegiatan disebabkan oleh tidak adanya peneduh untuk menangkal sinar matahari di siang hari pada tiap ruang terbuka publik tersebut. Sehingga sangat jarang penghuni perumahan yang 
menggunakan ruang terbuka publik pada siang hari terutama pada fasilitas yang tidak memiliki peneduhan.

Kurangnya nilai indeks variabel ini, disebabkan oleh pada waktu Hari Kerja dan waktu siang hari tidak ada aktivitas yang dilakukan pada tiap ruang terbuka publik tersebut. Menurut Carmona [1], bahwa lamanya waktu seseorang berada pada suatu ruang terbuka publik menunjukan adanya kenyamanan dalam menggunakan ruang tersebut. Sehingga dapat disimpulkan bahwa ruang terbuka publik pada tiap perumahan belum cukup nyaman untuk melakukan kegiatan pada setiap waktu.

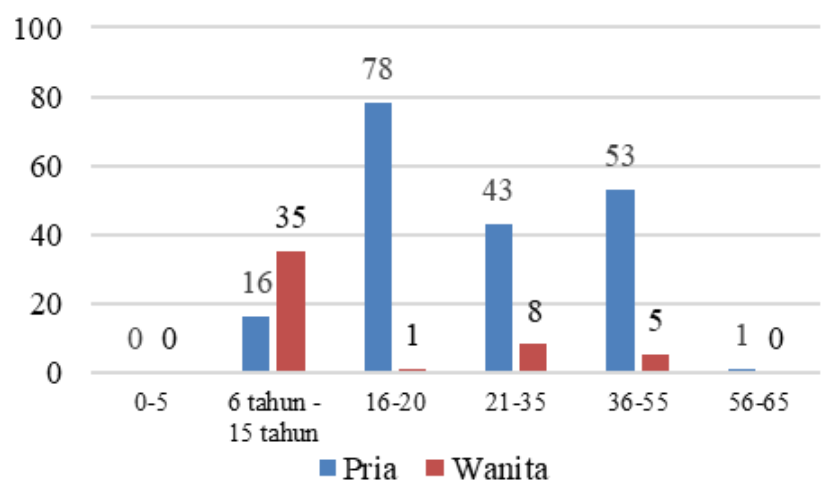

Gambar 8. Keragaman aktifitas pengguna

\subsubsection{Keragaman aktifitas pengguna}

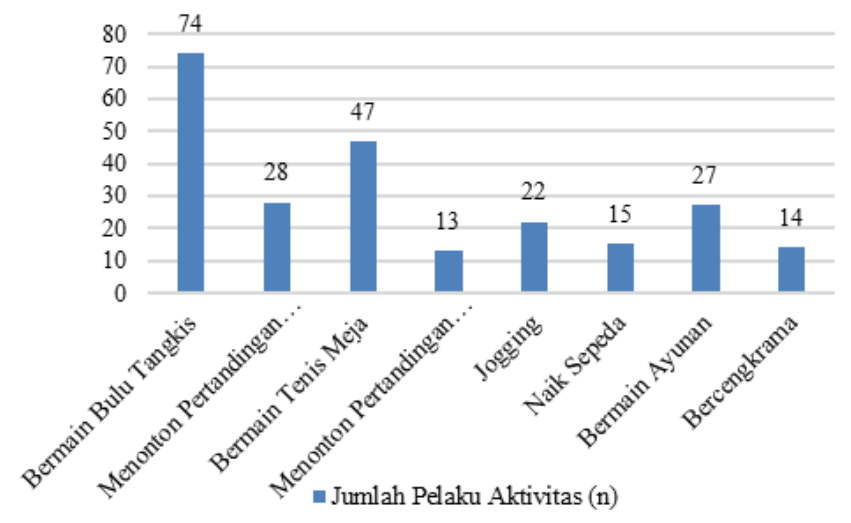

Gambar 9. Keragaman karakterisitik pengguna

Pada Gambar 8 efektifitas ruang terbuka hijau ditinjau berdasarkan keragaman aktifitas dengan menggunakan rumus Simpson's Index of Diversity yaitu :

$$
D=\frac{\text { Total } n(n-1)}{N(N-1)}
$$

Simpson's Index of Diversity $=(1-D)$

dimana:

$n \quad=$ Jumlah pelaku aktifitas

$N=$ Total (n) jumlah pelaku aktifitas

Berdasarkan rumus diatas diperoleh nilai Simpson's Index of Diversity yaitu 0,83. Nilai ini menunjukkan bahwa penggunaan ruang terbuka hijau cukup efektif jika ditinjau berdasarkan keragaman aktifitas pengguna. Pada Gambar 8 itu pula terlihat terdapat 8 jenis kegiatan yang dilakukan pengguna pada ruang terbuka yaitu Bermain bulu tangkis, menonton pertandingan bulu tangkis, bermain tenis meja, menonton pertandingan tenis meja, jogging, naik sepeda, Bermain ayunan, dan bercengkrama.

Pada Gambar 8 dapat terlihat bahwa kegiatan bermain bulu tangkis adalah kegiatan dengan jumlah pelaku tertinggi yaitu 74 orang, pada analisis ini kegiatan olahraga bulu tangkis adalah yang paling banyak digunakan karena banyaknya kelompok dalam komunitas ini yang meminatinya. Kegiatan yang dilakukan tidak selalu tergantung pada fasilitas yang disediakan [5]. Hal ini terlihat pada ruang terbuka publik di klaster borneo perumahan baruga yang indeks kualitas berdasarkan keragaman aktivitasnya sangat tinggi mendekati indeks 1 . Jenis kegiatan tidak hanya bergantung pada jumlah fasilitas yang disediakan menyebabkan indeks pada variable ini tinggi.

\subsubsection{Keragaman Karakteristik Pengguna}

Seperti halnya pada analisis sebelumnya, pada analisis efektifitas ruang terbuka berdasarkan keragaman karakteristik pengguna ini juga menggunakan nilai Simpson's Index of Diversity dan diperoleh nilai yaitu 0,78. Berdasarkan indikator indeks $0-1$, nilai ini menunjukkan penggunaan ruang terbuka cukup efektif jika ditinjau berdasarkan keragaman karakteristik penggunanya. 
Pada tabel ini pula dapat terlihat bahwa pengguna tertinggi adalah pria, sedangkan pengguna terendah adalah wanita. Sangat jelas bahwa pengguna wanita pada ruang terbuka ini sangat rendah. Pada tabel ini pula dapat terlihat bahwa berdasarkan usia pengguna tertinggi adalah pria berusia antara 16-20 tahun, 21-35 tahun dan 36-55 tahun.

Dari data di atas menunjukkan bahwa pria lebih sering beraktifitas di ruang terbuka dibandingkan dengan wanita, terlebih untuk pria berusia remaja dan dewasa. Pengguna ruang terbuka pada usia remaja ataupun pelajar cukup mendominasi karena masih banyaknya memiliki waktu dan energi untuk berinteraksi, namun jika pengguna usia dewasa yaitu usia 21-35 dan usia 36-55 di jumlahkan, maka kita dapat melihat bahwa pengguna usia dewasa adalah yang terbanyak, diketahui bahwa kalangan usia tersebut adalah inisiator dan donatur terbanyak dalam pembangunan ruang terbuka publik tersebut yang awalnya hanya berfungsi sebagai ruang terbuka hijau.

Karakteristik pengguna turut mempengaruhi penilaian kualitas ruang terbuka publik. Sebuah ruang terbuka publik yang dapat mewadahi berbagai jenis pengguna (Laki-laki, perempuan, anak-anak, dewasa muda, dan dewasa tua) akan menununjukkan tingkat kualitas ruang terbuka yang baik [5]. Berdasarkan variabel karakteristik pengguna, diperoleh indeks kualitas ruang terbuka publik yang cukup tinggi.

\section{Kesimpulan}

1) Ketersediaan Ruang Terbuka Publik dalam Perumahan Bukit Baruga, khususnya dalam Klaster Borneo telah memenuhi standar dan Peraturan Menteri Pekerjaan Umum Nomor 05/PRT/M/2008 tentang Pedoman Penyediaan dan pemanfaatan Ruang Terbuka di kawasan perkotaan, yaitu penyediaan ruang terbuka minimal $1 \mathrm{~m} 2 /$ kapita. Klaster Borneo memiliki jumlah warga yang cukup banyak yaitu 620 orang warga, sehingga ruang terbuka minimal yang disyaratkan adalah $620 \mathrm{~m} 2$, sementara ruang terbuka yang disediakan adalah $1.190 \mathrm{~m} 2$ yang sudah melebihi standar yang disyaratkan pada sebuah pemukiman dalam perkotaan. Kondisi fasilitas di dalam gated community tersebut juga diakui oleh para warga masih sangat baik dan rutin digunakan.

2) Berdasarkan analisis data primer dan sekunder menggunakan metode GPSI, didapatkan temuan-temuan mengenai efektivitas ruang terbuka publik dalam Perumahan Bukit Baruga Klaster Borneo yang menjawab pertanyaan-pertanyaan penelitian untuk mencapai tujuan penelitian :

a. Berdasarkan Intensitas Penggunaan pada hari kerja, index efektivitas menghasilkan nilai ratarata 0,175 , sedangkan pada hari libur, index efektivitas menghasilkan nilai rata-rata 0.290. Index skala tersebut menunjukkan ruang terbuka publik dalam klaster tersebut tidak efektif ditinjau dari intensitas penggunaanya.

b. Berdasarkan Penggunaannya secara Berkelompok atau Bersama, index efektivitas menghasilkan nilai 0.83 . Index skala tersebut menunjukkan ruang terbuka publik dalam klaster tersebut efektif ditinjau dari penggunaanya secara berkelompok.

c. Berdasarkan Durasi Penggunaan pada hari kerja, index efektivitas menghasilkan nilai ratarata 0.205, sedangkan pada hari libur, index efektivitas menghasilkan nilai rata-rata 0.334 . Index skala tersebut menunjukkan ruang terbuka publik dalam klaster tersebut tidak efektif ditinjau dari durasi penggunaanya.

d. Berdasarkan Keragaman Penggunanya, index efektivitas menghasilkan nilai 0.825. Index skala tersebut memperlihatkan ruang terbuka publik dalam klaster tersebut efektif ditinjau dari keragaman aktivitas pengguna di dalamnya.

e. Berdasarkan keragaman karakteristik penggunanya, index efektivitas menghasilkan nilai 0.79. Index skala tersebut menunjukkan ruang terbuka publik dalam klaster tersebut efektif ditinjau berdasarkan kergaman karakteristik penggunanya.

Berdasarkan 5 analisis tingkat penggunaan efektifitas ruang terbuka publik pada Gated Community terlihat bahwa penggunaan ruang terbuka efektif pada penggunaan secara berkelompok, keragaman aktivitas penggunanya, dan keragaman karakteristik penggunannya. 
Sedangkan terlihat tidak efektif pada intensitas penggunanya dan durasi penggunanya.

\section{Daftar pustaka}

[1] Carmona M., Magalhaes S., Hammond L. 2008. Architectural Press. Public space, the management dimension, Routledge, Taylor and Francis Group, London and New York.

[2] Carr, Stephen. 1992. Public Space. Cambridge : Cambridge University Press Carmona, Matthew, et al.
(2003). Public Space Urban Space : The Dimension of Urban Design . London: Architectural Press.

[3] Kementrian PU. 2009. Peraturan Menteri Pekerjaan Umum, 2009 No.12/PRT/M/2009 Tentang Pedoman Ruang Terbuka Non Hijau Di Wilayah Kota/Kawasan perkotaan. Jakarta.

[4] Mehta, Vikas. 2007. A Tool kit for Performance Measures of Public Space . 43rd ISOCARP Congress.

[5] Whyte, W. H. 1979. The Social Life of Small Urban Spaces. Washington: The Conservation Foundation. 